\title{
Governance, Institutions, and Economic Development
}

\begin{abstract}
Literature suggests a positive relationship between a country's social and economic development, good governance, and institutions. However, there is not a consensus on the nature of this relationship and the aspects of the governance that are most important for economic development. This paper addresses this question by empirically examining the relationship between a country's economic performance and governance indicators in 1996-2019. Economic performance indicators include GDP per capita and GDP. Governance indicators are adopted from the World Bank's Worldwide Governance Indicators. The paper shows that while most governance indicators have a positive and statistically significant impact on economic growth, their importance varies with the income level of the country. As such, improvements in different aspects of governance become more effective for economic growth as countries move through different stages of economic development.
\end{abstract}

Keywords: Economic Development; Institutions; Governance.

\section{Introduction}

While literature suggests a positive relationship between countries' social and economic development on the one hand and good governance and institutions on the other hand, empirical studies do not always support this hypothesis. The objective of this paper is to examine this issue by empirically testing the relationship between countries' economic performance and governance indicators. The paper uses the growth of the gross domestic product (GDP) per capita and GDP to measure a country's economic performance and the World Bank's Worldwide Governance Indicators (WGI) to measure governance. In particular, the study examines if certain aspects of governance are more important for economic growth than others and whether this relationship varies with the level of economic development. One difference of this study with the previous ones is that the annual changes of the governance indicators are used for the empirical study instead of their levels.

The study concludes that while based on correlations, there is a positive relationship between all aspects of governance and economic growth, more rigorous estimations suggest that improvements in certain aspects of governance such as political stability, the rule of law, and regulatory quality have a positive impact on economic growth for many countries regardless of their income level, that the first two are more important for lower-income countries, and that the third one is more important for higher-income countries. The study examines different variations of its empirical model to confirm the robustness of its findings.

The structure of the paper is as follows. Section 2 reviews the theoretical and empirical literature on the importance of good governance and institutions for development. This section also explains the governance indicators that are used in the study. Sections 3 and 4 explain the model and data sources. Section 5 presents the empirical findings. Section 6 concludes.

\section{Literature Review}

\subsection{Relationship between governance, institutions, and economic growth}




\section{Rashid Nikzad \\ Governance, Institutions, and Economic Development}

A large number of studies argue that good governance and institutions stimulate economic growth (North 1990, 2005; Knack and Keefer, 1995; Alston et al., 1996; Kaufmann et al., 1999; Kaufmann and Kraay 2002; Wage, 2003; United Nations, 2005; Acemoglu et al., 2005; Acemoglu and Robinson, 2010, 2012; Sachs, 2012). Some studies even consider good governance a prerequisite for growth (Kaufmann et al., 2005). The main points of these studies are summarized below.

Acemoglu et al. (2005) argue that differences in economic institutions are the major source of cross-country differences in economic growth and prosperity. Acemoglu and Robinson (2012) state that good institutions are important for economic growth and that "countries differ in their economic success because of their different institutions, the rules influencing how the economy works, and the incentives that motivate people." Good governance promotes growth by ensuring property rights, business transactions, social rights, and the provision of public goods (Fukuyama, 2014). Donors such as the International Monetary Fund (IMF), the World Bank, and the United States increasingly insist on performance and good governance as a prerequisite for aid (Nanda, 2006).

According to the World Bank (1997), sustainable development, both economic and social, is impossible without an effective state, and that "an effective state is vital for the provision of the goods and services as well as the rules and institutions that allow markets to flourish and people to lead healthier, happier lives." World Bank (2012) states that it needs to do better "in understanding issues of governance, institutions for development effectiveness, and ways to tackle corruption and malfeasance." This view is a shift from the World Bank's earlier view in which a minimal role for the government was assumed, mainly to address "market failure" and to efficient public management to achieve free-market economic development. The World Bank's recent view is also contrary to its earlier view that argued government interventions could result in large losses of efficiency and should therefore be selective (World Bank, 1983).

There are also studies that do not support the hypothesis that good governance and institutions stimulate economic growth (Quibria, 2006; Kurtz and Schrank, 2007). Rodrik (2008) shows that there are many countries that grow fast despite poor governance, rejecting the idea that good governance is a prerequisite for growth. He further argues that broad governance reform is neither necessary nor sufficient for growth. Also, while some studies suggest that institutions are an important factor economic growth and development, it is not possible to explain economic growth and development solely based on the institutional theory (Chang, 2011; Fukuyama, 2014).

There is also unclarity about the causality between good governance and economic growth. For example, while the World Bank study conducted by Kaufmann et al. (2005) argues that based on existing evidence, most of the correlation between governance and income per capita suggests causality from governance to growth and that "misgovernance" leads to low incomes, some studies state that growth comes first and good governance and institutions later (Glaeser et al., 2004; Chang, 2011).

\subsection{What is governance? What are institutions?}

Despite the abovementioned literature, most theories of economic growth do not explicitly include institutions and good governance in their models (Fukuyama, 2014). One of the issues pertains to the fact that there is not a consensus on the definition of governance. Some definitions for governance include "the manner in which power is exercised in the management of a country's economic and social resources for development" (World Bank, 1992), "rules, enforcement mechanisms, and organizations" (World Bank, 2002), and "what the state can do and how it does it" (World Bank, 2012). World Bank (2012) explains that what the state can do is determined by its capacity, legitimacy, and authority, where capacity is the ability of the state to procure and deliver goods and services, design and implement policies, build infrastructure, collect revenue, dispense justice, and maintain a conducive environment for the private sector; Legitimacy is whether citizens feel the government has the right to govern and whether they trust the government; and, authority is the ability of the state to govern its territory effectively, reach all citizens regardless of their location, gender, or ethnicity, maintain law and order and protect citizens from predation and violence. World Bank (2012) also states that governance includes questions such as how the state uses that capacity and authority, how accountable it is in using its power, and how transparent it is in its activities. Fukuyama (2013) defines governance as the government's ability to make and 


\section{Rashid Nikzad \\ Governance, Institutions, and Economic Development}

enforce rules, execute its functions, and deliver services, regardless of whether that government is democratic or not or whether the set goals are justified. According to this definition, an authoritarian regime can have good governance, while democracy can be maladministered.

There is not a clear definition for institutions either. North (1990) defines institutions as "the rules of the game in a society or, more formally, the humanly devised constraints that shape human interaction." According to Scott (2008), "institutions are social structures that have attained a high degree of resilience." Nanda (2006) argues that good governance includes political stability, governance reform and policy prescriptions to ensure transparency and the rule of law, accountability in public finances, control of corruption, accountability, improvement in governance standards, and creation of a productive private sector. Kraft and Furlong (2007) define the institutional theory as the "policy-making that emphasizes the formal and legal aspects of government structures." According to the World Bank (2012), institutions "establish the formal and informal rules that determine whether the public sector acts in its own interests or on behalf of all citizens".

When it comes to linking governance to public policy outcomes, it becomes even less clear what governance and institutions constitutes of, which dimensions of governance and which institutions are more important for the success of public policy, and how they can be created or measured (Fukuyama, 2014). According to Fukuyama (2014), a modern state and rule of law have a far greater influence on outcomes than democracy. Han et al. (2014) find that government effectiveness, political stability, control of corruption, and regulatory quality all have a more significant positive impact on country growth performance than voice and accountability and the rule of law for developing Asian Middle East and North African countries. Lehne et al. (2014) find that while economic and democratic institutions are closely linked, their relationship appears to be U-shaped rather than linear. They find that economic institutions tend to be better in countries that are more open to trade, investment, and financial flows and do not have significant natural resource endowments, and, that history and geography play an important role in shaping a country's economic institutions.

One of the limitations of the empirical studies that examine the relationship between governance and development is that there are few acceptable indicators of the quality of institutions and governance. Considering that the concept of good governance is not well defined, this problem becomes more profound when the indicators are used for comparisons across countries or over time. It should also be noted that some developing countries express concerns that the indicators reflect a pro-liberalization, pro-market, and Western type of governance model. Another issue even with acceptable indicators is that due to their aggragate nature, they do not give guidance on the concrete actions that need to be taken to improve the quality of governance (Kurtz and Shcrank, 2007; Arndt and Oman, 2008; Bevir, 2011; Norris, 2011; Davis, 2012; Fukuyama, 2013).

Nevertheless, different indicators have been developed by governments, international organizations, and non-governmental actors to assess governance and better understand the relationship between good governance and economic growth. Some commonly used measures of governance are as follows. The OECD evaluates government performance by defining measures for the inputs, processes, and outputs/outcomes of governments (OECD, 2021). Inputs include resources used by governments in their production function and the way they are combined. Processes refer to the public management practices and procedures undertaken by governments to implement policies. Outputs refer to the goods and services produced by governments. Outcomes show the ultimate effects of policies and practices on citizens and businesses.

The World Bank's Worldwide Governance Indicators (WGI), developed by Kaufmann and his colleagues (Kaufmann et al., 2010), are the most widely used measure to compare and evaluate governance performance in the context of economic development. Kaufmann et al. (2010) define governance as "the traditions and institutions by which authority in a country is exercised." They construct six indicators to measure three areas of governance:

(a) The process by which governments are selected, monitored, and replaced: 


\section{Rashid Nikzad \\ Governance, Institutions, and Economic Development}

1. Voice and Accountability (VA) to capture perceptions of the extent to which a country's citizens can participate in selecting their government, as well as freedom of expression, freedom of association, and free media.

2. Political Stability and Absence of Violence/Terrorism (PV) to capture perceptions of the likelihood that the government will be destabilized or overthrown by unconstitutional or violent means, including politically-motivated violence and terrorism.

(b) The capacity of the government to effectively formulate and implement sound policies:

3. Government Effectiveness (GE) to capture perceptions of the quality of public services, the quality of the civil service and the degree of its independence from political pressures, the quality of policy formulation and implementation, and the credibility of the government's commitment to such policies.

4. Regulatory Quality (RQ) to capture perceptions of the ability of the government to formulate and implement sound policies and regulations that permit and promote private sector development.

(c) The respect of citizens and the state for the institutions that govern economic and social interactions among them:

5. Rule of Law (RL) to capture perceptions of the extent to which agents have confidence in and abide by the rules of society, and in particular the quality of contract enforcement, property rights, the police, and the courts, as well as the likelihood of crime and violence.

6. Control of Corruption (CC) to capture perceptions of the extent to which public power is exercised for private gain, including both petty and grand forms of corruption, as well as "capture" of the state by elites and private interests.

The WGIs rely on perception-based governance data sources and aggregate individual governance indicators into the six indicators for over 200 economies since 1996. It should be noted that the six dimensions of governance are not independent of each other and that there are strong positive correlations among some of them (Arndt and Oman, 2008; Kaufmann et al., 2010).

There are also indicators that focus on specific aspects of governance. Examples include Transparency International, Global Integrity, Freedom House, Open Society Foundations, and Human Rights Watch, which address issues like human rights, basic social services, and environmental protection.

This study uses the World Bank's WGIs to examine the relationship between economic growth and governance. In particular, the study examines if certain aspects of governance are more important for economic growth than others. The next section explains the model that the study uses to test this hypothesis.

\section{Model}

Consistent with the literature, this study assumes that GDP is a function of labor, capital, openness to trade, and human capital. Governance indicators are also included to show their effects on economic growth (Equation 1):

$$
\begin{aligned}
& \text { GDP } \\
& =\text { Governance }^{\alpha_{g}} . \text { Population }^{\alpha_{p}} . \text { Invest }^{\alpha_{c}} . \text { Openness }^{\alpha_{o}} . \text { School }^{\alpha_{s}} . \text { Inflation }^{\alpha_{f}} . \text { InitialGDPCapita }^{\alpha_{n}}
\end{aligned}
$$

Both sides of Equation 1 are divided by population to re-write the model in terms of GDP per capita (GDPCapita):

$$
\begin{aligned}
& \text { GDPCapita } \\
& =\text { Governance }^{\alpha_{g}} . \text { Population }^{\alpha_{p 2}} . \text { Invest }^{\alpha_{c}} . \text { Openness }^{\alpha_{o}} . \text { School }^{\alpha_{s}} . \text { In }_{\text {Ilation }}{ }^{\alpha_{f}} . \text { InitialGDPCapita }^{\alpha_{n}}
\end{aligned}
$$

The model can be transformed to the following empirical model after taking the logarithm and first difference. Equation 2 assumes that economic growth, captured by the growth of GDP per capita, is a function of the growth of governance indicators, labor, capital, openness to trade, and human capital (Equation 2): 
Rashid Nikzad

Governance, Institutions, and Economic Development GDPCapita $_{i, t}=\alpha_{g}$ Governance $_{i, j, t}+\alpha_{l}$ GDPCapita $_{i, t-1}+\alpha_{p 2}$ Population $_{i, t}+\alpha_{c}$ Invest $_{i, t}+\alpha_{o}$ Openness $_{i, t}$
$+\alpha_{S}$ School $_{i, t}+\alpha_{f}$ Inflation $_{i, t}+\alpha_{n}$ InitialGDPCapita $_{i, t}+$ Dev $_{i}+\alpha_{t}+\varepsilon_{i, t}$

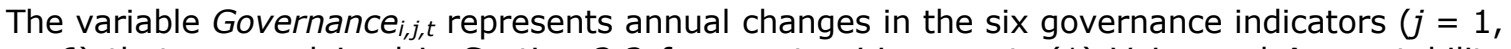
$\ldots, 6)$ that are explained in Section 2.2 for country $i$ in year $t$ : (1) Voice and Accountability (VA); (2) Political Stability and Absence of Violence/Terrorism (PV); (3) Government Effectiveness (GE); (4) Regulatory Quality (RQ); (5) Rule of Law (RL); (6) Control of Corruption (CC).

Labor growth is proxied by population growth (Population), capital growth is proxied by investment growth (Invest), openness to trade is proxied by the ratio of trade to GDP (Openness), and human capital is proxied by the rate of school enrollment (School). Higher investment, openness to trade, and school enrolment are expected to have a positive effect on economic growth. While population growth is expected to have a positive effect on the growth of GDP by providing more labor, it is expected to have a negative effect on GDP per capita because as population increases, GDP per capita decreases for the same level of GDP. The lag of GDP per capita is added to the empirical model to capture the autocorrelation effects of past GDP per capita.

Inflation (Inflation) and initial GDP per capita (InitialGDPCapita) are also included in the model and are expected to have a negative sign. High inflation is an indicator of weak macroeconomic policies. According to the convergence theory, there is a negative relationship between the initial GDP per capita and the growth of GDP per capita. The variable InitialGDPCapita also captures country-specific effects. Dev is a set of four dummy variables that shows the countries' level of economic development: consistent with the World Bank definition, countries are grouped as high-income, upper middle-income, lower middle-income, and low-income countries based on their GDP per capita (World Bank, 2020). Time dummies and the error term are represented by $a_{t}$ and $\varepsilon_{i, t}$. The next section presents data sources and the summary statistics of the variables.

\section{Data}

All economic variables are extracted from the World Bank's World Development Indicators (WDI). The governance indicators are obtained from the World Bank's Worldwide Governance Indicators (WGI). The WGIs range between -2.5 and 2.5, where a higher number means better governance and institutions. The sample includes over 200 countries for the period of 1996-2019. Tables 1 and 2 present the summary statistics of the economic (WDI) and governance (WGI) variables by the level of economic development.

Table 1: Summary Statistics of WDI (1996-2019) - By level of development

\begin{tabular}{|c|c|c|c|c|c|c|c|c|}
\hline Variable & $\begin{array}{l}\text { GDP per } \\
\text { Capita } \\
\text { Growth } \\
\end{array}$ & $\begin{array}{c}\text { GDP } \\
\text { Growth }\end{array}$ & $\begin{array}{l}\text { Population } \\
\text { growth }\end{array}$ & $\begin{array}{l}\text { Investment } \\
\text { Growth }\end{array}$ & $\begin{array}{l}\text { Trade } \\
\text { to GDP }\end{array}$ & $\begin{array}{l}\text { School } \\
\text { enrol. }\end{array}$ & Inflation & $\begin{array}{c}\text { Initial } \\
\text { GDP per } \\
\text { capita } \\
\end{array}$ \\
\hline \multicolumn{9}{|c|}{ All countries } \\
\hline Mean & 2.33 & 3.77 & 1.40 & 5.84 & 90.10 & 102.06 & 7.99 & 15206.05 \\
\hline Std. Dev. & 5.65 & 5.79 & 1.50 & 31.60 & 58.07 & 15.00 & 69.26 & 18542.13 \\
\hline \multicolumn{9}{|c|}{ High-income countries } \\
\hline Mean & 1.87 & 2.88 & 1.00 & 4.35 & 114.93 & 102.19 & 2.98 & 34172.71 \\
\hline Std. Dev. & 3.94 & 4.05 & 1.78 & 14.36 & 79.03 & 6.26 & 5.83 & 20608.67 \\
\hline \multicolumn{9}{|c|}{ Upper middle-income countries } \\
\hline Mean & 2.99 & 4.06 & 1.01 & 6.86 & 82.68 & 105.77 & 9.26 & 8657.14 \\
\hline Std. Dev. & 8.15 & 8.31 & 1.26 & 38.38 & 36.71 & 10.54 & 37.10 & 4084.96 \\
\hline \multicolumn{9}{|c|}{ Lower middle-income countries } \\
\hline Mean & 2.60 & 4.40 & 1.74 & 5.43 & 79.38 & 101.75 & 12.29 & 3511.42 \\
\hline
\end{tabular}


Rashid Nikzad

Governance, Institutions, and Economic Development

\begin{tabular}{|l|c|c|c|c|c|c|c|c|}
\hline Std. Dev. & 3.69 & 3.72 & 0.93 & 41.78 & 36.96 & 16.34 & 127.46 & 1599.93 \\
\hline Low-income countries \\
\hline Mean & 1.58 & 4.34 & 2.63 & 8.64 & 60.15 & 94.67 & 9.95 & 1322.76 \\
\hline Std. Dev. & 5.64 & 5.86 & 1.15 & 27.63 & 34.01 & 27.95 & 22.09 & 539.64 \\
\hline
\end{tabular}

As expected, Table 1 shows that the middle-income countries had the highest rate of growth of GDP per capita in 1996-2019, followed by high-income countries and low-income countries. However, the high standard deviation for the upper middle-income countries suggests large differences in the growth of these countries. Also, the ratio of trade to GDP increases by the level of income and, that high-income countries had the lowest inflation in this period.

Regarding the governance indicators, Table 2 suggests a positive relationship between all WGIs and the level of economic development such that all governance indicators increase monotonically with the level of economic development. Only the governance indicators of the high-income country group are positive. It should be noted that while Table 2 confirms a positive relationship between the level of economic development and good governance, it does not show the causality between the two.

Table 2: Summary Statistics of WGIs (1996-2019) - By level of development

\begin{tabular}{|c|c|c|c|c|c|c|}
\hline Variable & $\begin{array}{c}\text { Voice and } \\
\text { Accountability } \\
\text { (VA) }\end{array}$ & $\begin{array}{c}\text { Political Stab. and } \\
\text { Absence of } \\
\text { Violence/ Terrorism } \\
\text { (PV) } \\
\end{array}$ & $\begin{array}{c}\text { Government } \\
\text { Effectiveness } \\
\text { (GE) }\end{array}$ & $\begin{array}{l}\text { Regulatory } \\
\text { Quality } \\
\text { (RQ) }\end{array}$ & $\begin{array}{l}\text { Rule of } \\
\text { Law } \\
\text { (RL) }\end{array}$ & $\begin{array}{l}\text { Control of } \\
\text { Corruption } \\
\text { (CC) }\end{array}$ \\
\hline \multicolumn{7}{|c|}{ All countries } \\
\hline Mean & -0.0123 & -0.0048 & -0.0164 & -0.0181 & -0.0167 & -0.0206 \\
\hline Std. Dev. & 0.9969 & 0.9842 & 0.9884 & 0.9903 & 0.9908 & 0.9997 \\
\hline \multicolumn{7}{|c|}{ High-income countries } \\
\hline Mean & 0.8311 & 0.8078 & 1.0662 & 1.0456 & 1.0479 & 1.0454 \\
\hline Std. & 0.7344 & 0.5234 & 0.6597 & 0.6023 & 0.5962 & 0.7656 \\
\hline \multicolumn{7}{|c|}{ Upper middle-income countries } \\
\hline Mean & -0.1642 & -0.1362 & -0.2536 & -0.2608 & -0.3213 & -0.3295 \\
\hline Std. & 0.8397 & 0.8132 & 0.5835 & 0.6910 & 0.6574 & 0.6220 \\
\hline \multicolumn{7}{|c|}{ Lower middle-income countries } \\
\hline Mean & -0.4365 & -0.3927 & -0.5809 & -0.6076 & -0.5642 & -0.5840 \\
\hline Std. & 0.7269 & 0.8182 & 0.4407 & 0.4844 & 0.5445 & 0.5320 \\
\hline \multicolumn{7}{|c|}{ Low-income countries } \\
\hline Mean & -1.0168 & -1.0335 & -1.1115 & -1.0133 & -1.0443 & -0.9232 \\
\hline Std. & 0.6306 & 0.9078 & 0.5045 & 0.5987 & 0.5349 & 0.4666 \\
\hline
\end{tabular}

Tables 3 and 4 present the correlation matrix among the economic variables and the governance indicators. Table 4 suggests high correlations between Regulatory Quality (RQ), Rule of Law (RL), and Control of Corruption (CC). Although, as Appendix 1 suggests, this is mainly an issue for high-income countries.

Table 3: Correlation between the economic variables

\begin{tabular}{|l|c|c|c|c|c|c|c|}
\hline & $\begin{array}{c}\text { GDP per } \\
\text { Capita } \\
\text { Growth }\end{array}$ & $\begin{array}{c}\text { Population } \\
\text { growth }\end{array}$ & $\begin{array}{c}\text { Investment } \\
\text { Growth }\end{array}$ & $\begin{array}{c}\text { Trade } \\
\text { to GDP }\end{array}$ & $\begin{array}{c}\text { School } \\
\text { enrol. }\end{array}$ & $\begin{array}{c}\text { Initial } \\
\text { Inflation }\end{array}$ & $\begin{array}{c}\text { GDP per } \\
\text { capita }\end{array}$ \\
\hline GDP per Capita Growth & 1.0000 & & & & & & \\
\hline Population growth & -0.2056 & 1.0000 & & & & & \\
\hline Investment Growth & 0.1534 & 0.0136 & 1.0000 & & & & \\
\hline
\end{tabular}


Rashid Nikzad

Governance, Institutions, and Economic Development

\begin{tabular}{|l|c|c|c|c|c|c|c|}
\hline Trade to GDP & 0.0661 & -0.0878 & -0.0438 & 1.0000 & & & \\
\hline School enrol. & 0.0142 & -0.1316 & 0.0320 & 0.0086 & 1.0000 & & \\
\hline Inflation & -0.0505 & -0.0367 & 0.4667 & 0.0288 & 0.0093 & 1.0000 & \\
\hline Initial GDP per capita & -0.1637 & -0.1072 & -0.0334 & 0.3175 & 0.0214 & -0.0915 & 1.0000 \\
\hline
\end{tabular}

Since high correlation among the WGIs could lead to multicollinearity, and that the model uses the growth of the main economic variables, the annual changes of the WGIs are used instead of their levels to estimate Equation 2. Table 5 suggests that the correlation between the WGIs is reduced significantly when their annual changes are used.

Table 4: Correlation between the governance indicators

\begin{tabular}{|c|c|c|c|c|c|c|}
\hline & VA & PV & GE & RQ & RL & CC \\
\hline VA & 1.0000 & & & & & \\
\hline PV & 0.6745 & 1.0000 & & & & \\
\hline GE & 0.7575 & 0.6994 & 1.0000 & & & \\
\hline RQ & 0.7837 & 0.6549 & 0.9332 & 1.0000 & & \\
\hline RL & 0.8232 & 0.7809 & 0.9337 & 0.9040 & 1.0000 & \\
\hline CC & 0.7716 & 0.7411 & 0.9252 & 0.8653 & 0.9411 & 1.0000 \\
\hline
\end{tabular}

Table 5: Correlation between the changes of governance indicators

\begin{tabular}{|c|c|c|c|c|c|c|}
\hline & $\Delta \mathrm{VA}$ & $\Delta \mathrm{PV}$ & $\Delta \mathrm{GE}$ & $\Delta \mathrm{RQ}$ & $\Delta \mathrm{RL}$ & $\Delta \mathrm{CC}$ \\
\hline$\Delta \mathrm{VA}$ & 1.000 & & & & & \\
\hline$\Delta \mathrm{PV}$ & 0.1515 & 1.000 & & & & \\
\hline$\Delta \mathrm{GE}$ & 0.1378 & 0.1285 & 1.000 & & & \\
\hline$\Delta \mathrm{RQ}$ & 0.1258 & 0.1279 & 0.3532 & 1.000 & & \\
\hline$\Delta \mathrm{RL}$ & 0.2235 & 0.2102 & 0.2979 & 0.2474 & 1.000 & \\
\hline$\Delta \mathrm{CC}$ & 0.1674 & 0.0918 & 0.2862 & 0.2751 & 0.2644 & 1.000 \\
\hline
\end{tabular}

\section{Empirical Results}

Table 6 presents the regression results for all countries, with and without governance indicators, and for different income levels. The coefficients of all variables are consistent with the theory explained in Section 3: Investment growth and openness have a positive impact on the growth of GDP per capita, although the impact of openness is statistically significant only for higher-income countries. Population growth and inflation have a negative and statistically significant impact on the growth of GDP per capita of almost all income levels. The initial GDP per capita is statistically significant, but its coefficient is almost zero. The impact of the school enrolment is insignificant, which suggests it may not be a good indicator for human capital.

Since some of the economic and governance variables may be subject to the endogeneity problem, Table 7 repeats the estimations using the generalized method of moments (GMM) to control for endogeneity. The results are consistent with the Generalized least squares (GLS) estimates in Table 6. Regarding the changes in the governance indicators, changes in Political Stability and Absence of Violence/Terrorism (PV), Regulatory Quality (RQ), and Rule of Law $(R L)$ show a positive impact on the growth of GDP per capita roughly for all income groups, but their significances vary with the level of income. Changes in Voice and Accountability (VA) have either a negative or statistically insignificant impact. Changes in Government Effectiveness (GE) and Control of Corruption (CC) have a statistically insignificant impact.

Tables 6 and 7 also suggest that improvements in Political Stability and Absence of Violence/Terrorism (PV) and Rule of Law (RL) are more important for lower-income countries 


\section{Rashid Nikzad}

Governance, Institutions, and Economic Development

to achieve higher economic growth than for high-income countries. In comparison, improvements in Regulatory Quality (RQ) is more important for higher-income countries.

Two findings are inconsistent with theory: changes in Government Effectiveness (GE) and Control of Corruption (CC) are either statistically insignificant or have a negative impact, especially for lower-income countries. There could be different explanations for it. One explanation is measurement issues of this indicator, especially for lower-income countries. Another explanation is the high correlation between Government Effectiveness (GE) and other variables as Table 4 and Appendix 1 suggest. While the study uses the changes in the governance indicators, the indicators may still suffer from multicollinearity.

Table 6: GDP per capita growth and governance, 1996-2019

\begin{tabular}{|c|c|c|c|c|c|c|}
\hline GDP per capita growth & $\begin{array}{c}\text { All } \\
\text { countries }\end{array}$ & $\begin{array}{c}\text { All } \\
\text { countries }\end{array}$ & $\begin{array}{l}\text { High- } \\
\text { income } \\
\text { countries }\end{array}$ & $\begin{array}{l}\text { High middle- } \\
\text { income } \\
\text { countries }\end{array}$ & $\begin{array}{l}\text { Low middle- } \\
\text { income } \\
\text { countries }\end{array}$ & $\begin{array}{c}\text { Low- } \\
\text { income } \\
\text { countries }\end{array}$ \\
\hline$\Delta \mathrm{VA}$ & & $\begin{array}{c}-0.825 \\
(0.872)\end{array}$ & $\begin{array}{c}-3.071 * * \\
(1.474)\end{array}$ & $\begin{array}{c}-1.338 \\
(0.896)\end{array}$ & $\begin{array}{c}-1.465^{*} \\
(0.904)\end{array}$ & $\begin{array}{c}1.948 \\
(1.981)\end{array}$ \\
\hline$\triangle \mathrm{PV}$ & & $\begin{array}{c}1.137 * * * \\
(0.292)\end{array}$ & $\begin{array}{c}0.767 * \\
(0.503)\end{array}$ & $\begin{array}{c}0.368 \\
(0.558)\end{array}$ & $\begin{array}{c}1.342 * \\
(0.687)\end{array}$ & $\begin{array}{l}1.137 * \\
(0.606)\end{array}$ \\
\hline$\Delta \mathrm{GE}$ & & $\begin{array}{c}-0.109 \\
(0.613)\end{array}$ & $\begin{array}{c}0.130 \\
(0.805)\end{array}$ & $\begin{array}{c}-0.137 \\
(0.913)\end{array}$ & $\begin{array}{c}1.210 \\
(0.971)\end{array}$ & $\begin{array}{c}-2.108 \\
(3.025)\end{array}$ \\
\hline$\Delta \mathrm{RQ}$ & & $\begin{array}{c}1.758 * * * \\
(0.544)\end{array}$ & $\begin{array}{c}1.927 * * * \\
(0.567)\end{array}$ & $\begin{array}{c}1.643^{*} \\
(1.078)\end{array}$ & $\begin{array}{c}0.654 \\
(0.939)\end{array}$ & $\begin{array}{c}-0.547 \\
(2.547)\end{array}$ \\
\hline$\Delta \mathrm{RL}$ & & $\begin{array}{l}1.441^{*} \\
(0.889)\end{array}$ & $\begin{array}{l}1.361^{*} \\
(0.869)\end{array}$ & $\begin{array}{c}-0.327 \\
(1.500)\end{array}$ & $\begin{array}{l}1.424^{*} \\
(0.921)\end{array}$ & $\begin{array}{c}6.140 * \\
(3.816)\end{array}$ \\
\hline$\Delta \mathrm{CC}$ & & $\begin{array}{c}0.587 \\
(1.017)\end{array}$ & $\begin{array}{c}2.097 \\
(1.583)\end{array}$ & $\begin{array}{c}-0.062 \\
(1.099)\end{array}$ & $\begin{array}{c}-0.263 \\
(0.912)\end{array}$ & $\begin{array}{l}-3.921 \\
(2.611)\end{array}$ \\
\hline Lag of GDP per capita growth & $\begin{array}{c}0.383 * * * \\
(0.036)\end{array}$ & $\begin{array}{c}0.374 * * * \\
(0.036)\end{array}$ & $\begin{array}{c}0.363 * * * \\
(0.042)\end{array}$ & $\begin{array}{c}0.368 * * * \\
(0.088)\end{array}$ & $\begin{array}{c}0.328 * * * \\
(0.055)\end{array}$ & $\begin{array}{c}0.260 * * * \\
(0.062)\end{array}$ \\
\hline Population growth & $\begin{array}{c}-0.477 * * * \\
(0.064)\end{array}$ & $\begin{array}{c}-0.476 * * * \\
(0.064)\end{array}$ & $\begin{array}{c}-0.416 * * * \\
(0.066)\end{array}$ & $\begin{array}{c}-0.764 * * * \\
(0.169)\end{array}$ & $\begin{array}{c}-0.633 * * * \\
(0.128)\end{array}$ & $\begin{array}{c}0.539 \\
(0.626)\end{array}$ \\
\hline Investment growth & $\begin{array}{c}0.024 * \\
(0.014)\end{array}$ & $\begin{array}{c}0.023^{*} \\
(0.014)\end{array}$ & $\begin{array}{c}0.079 * * * \\
(0.019)\end{array}$ & $\begin{array}{c}0.042 * * \\
(0.018)\end{array}$ & $\begin{array}{c}0.007 \\
(0.007)\end{array}$ & $\begin{array}{c}0.039 * * * \\
(0.013)\end{array}$ \\
\hline Openness & $\begin{array}{c}0.007 * * * \\
(0.002)\end{array}$ & $\begin{array}{c}0.008 * * * \\
(0.002)\end{array}$ & $\begin{array}{c}0.006 * * * \\
(0.001)\end{array}$ & $\begin{array}{c}0.006 \\
(0.006)\end{array}$ & $\begin{array}{c}0.004 \\
(0.004)\end{array}$ & $\begin{array}{c}0.015 \\
(0.010)\end{array}$ \\
\hline School enrollment & $\begin{array}{c}-0.004 \\
(0.006)\end{array}$ & $\begin{array}{c}-0.003 \\
(0.006)\end{array}$ & $\begin{array}{l}-0.001 \\
(0.016)\end{array}$ & $\begin{array}{c}0.000 \\
(0.017)\end{array}$ & $\begin{array}{c}0.002 \\
(0.011)\end{array}$ & $\begin{array}{c}-0.009 \\
(0.011)\end{array}$ \\
\hline Inflation & $\begin{array}{c}-0.031 * * * \\
(0.011)\end{array}$ & $\begin{array}{c}-0.031 * * * \\
(0.011)\end{array}$ & $\begin{array}{c}-0.045 * * * \\
(0.010)\end{array}$ & $\begin{array}{c}-0.047 * * * \\
(0.016)\end{array}$ & $\begin{array}{c}0.017 * * \\
(0.008)\end{array}$ & $\begin{array}{c}0.009 \\
(0.036)\end{array}$ \\
\hline Initial GDP per capita & $\begin{array}{c}-0.000 * * * \\
(0.000)\end{array}$ & $\begin{array}{c}-0.000 * * * \\
(0.000)\end{array}$ & $\begin{array}{c}-0.000 * * * \\
(0.000)\end{array}$ & $\begin{array}{c}-0.000 * * * \\
(0.000)\end{array}$ & $\begin{array}{c}-0.000 * * * \\
(0.000)\end{array}$ & $\begin{array}{c}-0.001 \\
(0.001)\end{array}$ \\
\hline Dev: High income & $\begin{array}{c}-0.314 \\
(0.400)\end{array}$ & $\begin{array}{l}-0.277 \\
(0.403)\end{array}$ & & & & \\
\hline Dev: Upper middle-income & $\begin{array}{c}0.132 \\
(0.372)\end{array}$ & $\begin{array}{c}0.099 \\
(0.378)\end{array}$ & & & & \\
\hline Dev: Lower middle-income & $\begin{array}{c}0.217 \\
(0.316)\end{array}$ & $\begin{array}{c}0.216 \\
(0.321)\end{array}$ & & & & \\
\hline Constant & $\begin{array}{c}2.018 * * * \\
(0.689)\end{array}$ & $\begin{array}{c}1.908 * * * \\
(0.693)\end{array}$ & $\begin{array}{c}0.343 \\
(2.640)\end{array}$ & $\begin{array}{l}3.471 * \\
(1.871)\end{array}$ & $\begin{array}{c}2.965 * * \\
(1.264)\end{array}$ & $\begin{array}{c}0.028 \\
(2.900)\end{array}$ \\
\hline Observations & 2,686 & 2,681 & 1,008 & 618 & 738 & 317 \\
\hline
\end{tabular}

Generalized least squares (GLS) estimates. Robust standard errors in parentheses; *** $p<0.01, * *$ $\mathrm{p}<0.05, * \mathrm{p}<0.1$; P-values for $\triangle \mathrm{PV}$ and $\Delta \mathrm{RL}$ for high income countries are 0.127 and 0.117 , for $\Delta R Q$ for high middle-income countries is 0.128 , and for $\Delta R L$ for low middle-income and low-income countries are 0.122 and 0.108 .

As additional tests, Appendix 2 presents the results of the regressions per individual governance indicator per income group. In this case, the impacts of the changes in all governance indicators become positive and statistically significant for all countries (Tables A2.1 and A2.2) except for Voice and Accountability (VA), which is statistically insignificant. Appendix 3 presents the regressions results for GDP instead of GDP per capita. The results are consistent with those in Tables 6 and 7.

\section{CONCLUSION}


The objective of this study was to examine the relationship between countries' economic growth and governance indicators. To do so, the annual changes of governance indicators were included in a model that captures the growth of GDP per capita. Empirical results suggest a positive and statistically significant relationship between most governance indicators and economic growth. However, the importance and significance of the individual governance indicators change with the level of economic development.

First, a simple correlation suggests a positive relationship between all WGIs and the level of economic development such that all governance indicators increase monotonically with the level of economic development. Second, changes in Political Stability and Absence of Violence/Terrorism (PV), Regulatory Quality (RQ), and Rule of Law (RL) show a positive impact on the growth of GDP per capita roughly for all income groups, but their significances vary with the level of income. Changes in Voice and Accountability (VA) have either a negative or insignificant impact. Changes in Government Effectiveness (GE) and Control of Corruption (CC) have a statistically insignificant impact. Third, improvements in Political Stability and Absence of Violence/Terrorism (PV) and Rule of Law (RL) are more important for lower-income countries to achieve higher economic growth than for high-income countries, while improvements in Regulatory Quality (RQ) is more important for higher-income countries. However, changes in Government Effectiveness (GE) and Control of Corruption (CC) are either statistically insignificant or have a negative impact, especially for lower-income countries. This result could be due to measurement errors for low-income countries or a high correlation between Government Effectiveness (GE) and other variables. To support the latter hypothesis, regression results based on individual governance indicators suggest a positive and statistically significant impact of good governance on economic growth for all income levels for all governance indicators except for Voice and Accountability (VA).

Table 7: GDP per capita growth and governance, 1996-2019; GMM estimations

\begin{tabular}{|c|c|c|c|c|c|c|}
\hline GDP per capita growth & $\begin{array}{c}\text { All } \\
\text { countries }\end{array}$ & $\begin{array}{c}\text { All } \\
\text { countries }\end{array}$ & $\begin{array}{c}\text { High- } \\
\text { income } \\
\text { countries }\end{array}$ & $\begin{array}{c}\text { High middle- } \\
\text { income countries }\end{array}$ & $\begin{array}{l}\text { Low middle- } \\
\text { income } \\
\text { countries }\end{array}$ & $\begin{array}{c}\text { Low- } \\
\text { income } \\
\text { countries }\end{array}$ \\
\hline \multirow[t]{2}{*}{$\Delta \mathrm{VA}$} & & -0.803 & $-3.072^{* *}$ & $-1.344 *$ & $-1.467^{*}$ & 1.948 \\
\hline & & (0.859) & $(1.433)$ & $(0.859)$ & $(0.872)$ & $(1.821)$ \\
\hline \multirow[t]{2}{*}{$\triangle \mathrm{PV}$} & & $1.130 * * *$ & 0.767 & 0.370 & $1.337 * *$ & $1.137 * *$ \\
\hline & & $(0.289)$ & $(0.489)$ & $(0.534)$ & $(0.663)$ & $(0.557)$ \\
\hline \multirow[t]{2}{*}{$\Delta \mathrm{GE}$} & & -0.114 & 0.131 & -0.139 & 1.210 & -2.108 \\
\hline & & $(0.610)$ & $(0.783)$ & $(0.873)$ & $(0.936)$ & $(2.780)$ \\
\hline \multirow[t]{2}{*}{$\Delta \mathrm{RQ}$} & & $1.737 * * *$ & $1.927 * * *$ & $1.644 *$ & 0.653 & -0.547 \\
\hline & & $(0.534)$ & $(0.552)$ & $(1.032)$ & $(0.905)$ & $(2.341)$ \\
\hline \multirow[t]{2}{*}{$\Delta \mathrm{RL}$} & & 1.420 & 1.362 & -0.326 & $1.412 *$ & $6.140 *$ \\
\hline & & $(0.885)$ & $(0.847)$ & (1.434) & $(0.888)$ & (3.507) \\
\hline \multirow[t]{2}{*}{$\Delta \mathrm{CC}$} & & 0.588 & 2.096 & -0.064 & -0.264 & $-3.921 *$ \\
\hline & & $(1.010)$ & $(1.540)$ & $(1.051)$ & $(0.879)$ & $(2.400)$ \\
\hline Lag of GDP per capita growth & $\begin{array}{c}0.394 * * * \\
(0.038)\end{array}$ & $\begin{array}{c}0.384 * * * \\
(0.038)\end{array}$ & $\begin{array}{c}0.363 * * * \\
(0.041)\end{array}$ & $\begin{array}{c}0.366 * * * \\
(0.084)\end{array}$ & $\begin{array}{c}0.332 * * * \\
(0.053)\end{array}$ & $\begin{array}{c}0.260 * * * \\
(0.057)\end{array}$ \\
\hline Population growth & $\begin{array}{c}-0.471 * * * \\
(0.063)\end{array}$ & $\begin{array}{c}-0.471 * * * \\
(0.063)\end{array}$ & $\begin{array}{c}-0.416 * * * \\
(0.064)\end{array}$ & $\begin{array}{c}-0.765^{* * *} \\
(0.162)\end{array}$ & $\begin{array}{c}-0.630 * * * \\
(0.123)\end{array}$ & $\begin{array}{c}0.539 \\
(0.575)\end{array}$ \\
\hline Investment growth & $\begin{array}{l}0.023^{*} \\
(0.014)\end{array}$ & $\begin{array}{l}0.022 * \\
(0.013)\end{array}$ & $\begin{array}{c}0.079 * * * \\
(0.018)\end{array}$ & $\begin{array}{l}0.042 * * \\
(0.018)\end{array}$ & $\begin{array}{c}0.007 \\
(0.007)\end{array}$ & $\begin{array}{c}0.039 * * * \\
(0.012)\end{array}$ \\
\hline Openness & $\begin{array}{l}0.007 * * * \\
(0.002)\end{array}$ & $\begin{array}{c}0.007 * * * \\
(0.002)\end{array}$ & $\begin{array}{c}0.006 * * * \\
(0.001)\end{array}$ & $\begin{array}{c}0.006 \\
(0.006)\end{array}$ & $\begin{array}{c}0.004 \\
(0.003)\end{array}$ & $\begin{array}{l}0.015^{*} \\
(0.009)\end{array}$ \\
\hline School enrollment & $\begin{array}{l}-0.003 \\
(0.006)\end{array}$ & $\begin{array}{l}-0.003 \\
(0.006)\end{array}$ & $\begin{array}{l}-0.001 \\
(0.016)\end{array}$ & $\begin{array}{c}0.000 \\
(0.016)\end{array}$ & $\begin{array}{c}0.002 \\
(0.010)\end{array}$ & $\begin{array}{l}-0.009 \\
(0.010)\end{array}$ \\
\hline Inflation & $\begin{array}{c}-0.031 * * * \\
(0.011)\end{array}$ & $\begin{array}{c}-0.031 * * * \\
(0.011)\end{array}$ & $\begin{array}{c}-0.045 * * * \\
(0.010)\end{array}$ & $\begin{array}{c}-0.047 * * * \\
(0.016)\end{array}$ & $\begin{array}{l}0.016 * * \\
(0.008)\end{array}$ & $\begin{array}{l}0.009 \\
(0.033)\end{array}$ \\
\hline Initial GDP per capita & $\begin{array}{c}-0.000 * * * \\
(0.000)\end{array}$ & $\begin{array}{c}-0.000 * * * \\
(0.000)\end{array}$ & $\begin{array}{c}-0.000 * * * \\
(0.000)\end{array}$ & $\begin{array}{c}-0.000 * * * \\
(0.000)\end{array}$ & $\begin{array}{c}-0.000 * * * \\
(0.000)\end{array}$ & $\begin{array}{l}-0.001 \\
(0.001)\end{array}$ \\
\hline Dev: High income & $\begin{array}{l}-0.322 \\
(0.390)\end{array}$ & $\begin{array}{l}-0.286 \\
(0.393)\end{array}$ & & & & \\
\hline Dev: Upper middle-income & $\begin{array}{c}0.122 \\
(0.363)\end{array}$ & $\begin{array}{c}0.091 \\
(0.368)\end{array}$ & & & & \\
\hline Dev: Lower middle-income & $\begin{array}{c}0.209 \\
(0.309)\end{array}$ & $\begin{array}{c}0.208 \\
(0.313)\end{array}$ & & & & \\
\hline Constant & $\begin{array}{l}-1.475 * * \\
(0.689)\end{array}$ & $\begin{array}{l}-1.531 * * \\
(0.686)\end{array}$ & $\begin{array}{c}1.374 \\
(1.628) \\
\end{array}$ & $\begin{array}{c}4.042 * * \\
(1.818) \\
\end{array}$ & $\begin{array}{c}4.273 * * * \\
(1.227)\end{array}$ & $\begin{array}{c}1.933 \\
(2.308) \\
\end{array}$ \\
\hline Observations & 2,686 & 2,681 & 1,008 & 618 & 738 & 317 \\
\hline
\end{tabular}




\section{Rashid Nikzad \\ Governance, Institutions, and Economic Development}

Generalized method of moments (GMM) estimates. Robust standard errors in parentheses; $* * * p<0.01$, ** $\mathrm{p}<0.05, * \mathrm{p}<0.1$; $\mathrm{P}$-values for $\triangle \mathrm{RL}$ for all countries is 0.109 , for $\triangle \mathrm{PV}$ and $\triangle \mathrm{RL}$ for high-income countries are 0.117 and 0.108 , for $\triangle \mathrm{VA}$ and $\triangle \mathrm{RQ}$ for high middle-income countries are 0.118 and 0.111 , and for $\Delta R L$ for low middle-income countries is 0.112 .

\section{DISCLAIMER}

The view and analysis presented in this paper are solely those of the author.

\section{REFERENCES}

- Alston, L. J., T. Eggertsson, and D. C. North. (1996). "Empirical Studies in Institutional Change." Cambridge University Press. Crossref

- Arndt, C. and C. Oman. (2008). "The Politics of Governance Ratings", Maastricht: Maastricht University.

- Acemoglu, D., S. Johnson, and J. A. Robinson. (2005). "Institutions as a Fundamental Cause of Long-Run Growth." in Aghion, P. and S. Durlauf, "Handbook of Economic Growth." Elsevier, Amsterdam. Crossref

- Acemoglu, D., and J. A. Robinson. (2010). "The role of institutions in growth and development." Review of Economic Institutions, 1(2). Crossref

- Acemoglu, D. and J.A. Robinson. (2012). "Why Nations Fail: The Origins of Power, Prosperity, and Poverty." New York: Crown Business. Crossref

- Bevir, M. (2011). "The SAGE Handbook of Governance." SAGE Publications Ltd.

- Chang, H. (2011). "Institutions and economic development: theory, policy and history." Journal of Institutional Economics, 7(4), pp. 473-498. Crossref

- Davis, K., A. Fisher, B. Kingsbury, and S. E. Merry. (2012). "Governance by Indicators: Global Power through Classification and Rankings." Oxford: Oxford University Press, Chapter 1. Crossref

- Fukuyama, Francis. (2013). "What is governance?" Governance, 26(3), pp. 347-367. Crossref

- Fukuyama, Francis. (2014). "The end of harmony." The Economist, September 25th.

- Glaeser, E. L., R. La Porta, F. Lopez-de-Silanes, and A. Shleifer. (2004). "Do Institutions Cause Growth?" Journal of Economic Growth, vol. 9(3), pp. 271303. Crossref

- Han, X., H. Khan, and J. Zhuang. (2014). "Do Governance Indicators Explain Development Performance? A Cross Country Analysis." Manila: Asian Development Bank. Crossref

- Kaufmann, D., A. Kraay and P. Zoido-Lobatón. (1999). "Governance matters." In World Bank, Policy research working paper 2196.

- Kaufman, D. and A. Kraay. (2002). "Growth without Governance." Economía, 3(1), pp. 169-215. Crossref

- Kaufmann, D, A. Kraay and M. Mastruzzi. (2005). "Governance Matters IV: Governance Indicators for 1996-2004." World Bank Policy Research Working Paper Series No. 3630. Crossref

- Kaufmann, D., A. Kraay, and M. Mastruzzi. (2010). "The Worldwide Governance Indicators: Methodology and Analytical Issues." The World Bank, Institute Global Governance, Policy Research Working Paper 5430.

- Knack, S. and P. Keefer. (1995). "Institutions and Economic Performance: CrossCountry Tests Using Alternative Institutional Indicators." Economics and Politics, 7(3), pp. 207-228. Crossref

- Kraft, M. E., and S. R. Furlong. (2007). "Public Policy: politics, analysis, and alternatives." CQ; London: Eurospan, Washington, D.C.

- Kurtz, J. M. and A. Schrank. (2007). "Growth and Governance: Models, Measures, and Mechanisms." Journal of Politics, 69 (2), pp. 538-554. Crossref

- Lehne, J., J. Mo and A. Plekhanov. (2014). "What determines the quality of economic institutions? Cross-country evidence." European Bank for Reconstruction and Development, Working Paper No. 171. Crossref

- Norris, P. (2011). "Measuring Governance." in Bevir, M., "The Sage Handbook of Governance." Sage. Crossref

- Nanda, V.D. (2006). "The "Good Governance" Concept Revisited." The Annals of the American Academy, 603, pp. 269-280. Crossref

- North, D. C. (1990). "Institutions, Institutional Change, and Economic Performance." New York: Cambridge University Press. Crossref 
- North, D. C. (2005). "Understanding the Process of Economic Change." Princeton University Press. Crossref

- OECD. (2021). "Government at a Glance 2021." Paris: OECD.

- Quibria, M. G. (2006). "Does Governance Matter? Yes, No or Maybe: Some Evidence from Developing Asia." Kyklos, 59(1), pp. 99-114. Crossref

- Rodrik, D. (2008). "Thinking about Governance." in World Bank, "Governance, Growth and Development Decision-Making." World Bank, Washington DC.

- Sachs, J. D. (2012), "Reply to Acemoglu and Robinson's Response to my Book Review." http://jeffsachs.org/2012/12/reply-to-acemoglu-and-robinsons-response-tomy-book-review/.

- Scott, W. R. (2008). "Institutions and Organizations: Ideas and Interests." 3rd edition, Thousand Oaks: Sage.

- United Nations. (2005). "Investing in Development. A practical Plan to Achieve the Millennium Development Goals." Millennium Project Report to the UN SecretaryGeneral, New York, NY.

- Wade, R. (2003). "Governing the Market: Economic Theory and the Role of Government in East Asian Industrialization." Princeton, Princeton University Press.

- World Bank. (1983). "World Development Report 1983." New York: Oxford University Press. Crossref

- World Bank. (1997). "World Development Report 1997: The State in a Changing World." New York: Oxford University Press. Crossref

- World Bank. (2002). "World Development Report 2002: Building Institutions for Markets." New York: Oxford University Press.

- World Bank. (2012). "Strengthening Governance: Tackling Corruption." The World Bank Group's Updated Strategy and Implementation Plan.

- World Bank. (2020). "The world by income", https://datatopics.worldbank.org/world-development-indicators/the-world-byincome-and-region.html.

\section{Appendix 1 - Correlation between the governance indicators by income level}

a) High-income countries

\begin{tabular}{|c|c|c|c|c|c|c|}
\hline & VA & PV & GE & RQ & RL & CC \\
\hline VA & 1.0000 & & & & & \\
\hline PV & 0.4023 & 1.0000 & & & & \\
\hline GE & 0.5423 & 0.4529 & 1.0000 & & & \\
\hline RQ & 0.5180 & 0.3593 & 0.8657 & 1.0000 & & \\
\hline RL & 0.6362 & 0.5168 & 0.8838 & 0.8208 & 1.0000 & \\
\hline CC & 0.5399 & 0.5045 & 0.8942 & 0.7900 & 0.9016 & 1.0000 \\
\hline
\end{tabular}

b) High middle-income countries

\begin{tabular}{|c|c|c|c|c|c|c|}
\hline & VA & PV & GE & RQ & RL & CC \\
\hline VA & 1.0000 & & & & & \\
\hline PV & 0.4538 & 1.0000 & & & & \\
\hline GE & 0.5349 & 0.3691 & 1.0000 & & & \\
\hline RQ & 0.6398 & 0.2722 & 0.8218 & 1.0000 & & \\
\hline RL & 0.7269 & 0.6444 & 0.7644 & 0.7148 & 1.0000 & \\
\hline CC & 0.6590 & 0.5808 & 0.7668 & 0.6422 & 0.8345 & 1.0000 \\
\hline
\end{tabular}

c) Low middle-income countries

\begin{tabular}{|l|c|l|l|l|l|l|}
\hline & VA & PV & GE & RQ & RL & CC \\
\hline VA & 1.0000 & & & & & \\
\hline PV & 0.4358 & 1.0000 & & & & \\
\hline
\end{tabular}


Rashid Nikzad

Governance, Institutions, and Economic Development

\begin{tabular}{|l|l|l|l|l|l|l|}
\hline GE & 0.3881 & 0.3420 & 1.0000 & & & \\
\hline RQ & 0.4796 & 0.2240 & 0.6798 & 1.0000 & & \\
\hline$R L$ & 0.6533 & 0.5591 & 0.7385 & 0.5894 & 1.0000 & \\
\hline CC & 0.5640 & 0.5913 & 0.6843 & 0.4232 & 0.8340 & 1.0000 \\
\hline
\end{tabular}


Rashid Nikzad

Governance, Institutions, and Economic Development

d) Low-income countries

\begin{tabular}{|c|c|c|c|c|c|c|}
\hline & VA & PV & GE & RQ & RL & CC \\
\hline VA & 1.0000 & & & & & \\
\hline PV & 0.4951 & 1.0000 & & & & \\
\hline GE & 0.5508 & 0.5255 & 1.0000 & & & \\
\hline RQ & 0.7272 & 0.4961 & 0.8329 & 1.0000 & & \\
\hline RL & 0.6044 & 0.7294 & 0.8177 & 0.7859 & 1.0000 & \\
\hline CC & 0.4435 & 0.5511 & 0.7480 & 0.6363 & 0.7694 & 1.0000 \\
\hline
\end{tabular}

Appendix 2 - Regression results per individual governance indicator

Table A2.1: GDP per capita growth and governance, 1996-2019 - All countries

\begin{tabular}{|c|c|c|c|c|c|c|c|}
\hline GDP per capita growth & & $\Delta \mathrm{VA}$ & $\Delta \mathrm{PV}$ & $\Delta \mathrm{GE}$ & $\Delta \mathrm{RQ}$ & $\Delta \mathrm{RL}$ & $\triangle \mathrm{CC}$ \\
\hline Governance indicator & & $\begin{array}{c}0.104 \\
(0.895)\end{array}$ & $\begin{array}{c}1.359 * * * \\
(0.301)\end{array}$ & $\begin{array}{c}1.061^{*} \\
(0.563)\end{array}$ & $\begin{array}{c}2.375 * * * \\
(0.620)\end{array}$ & $\begin{array}{c}2.391^{* * *} \\
(0.921)\end{array}$ & $\begin{array}{c}1.432 * \\
(0.949)\end{array}$ \\
\hline Lag of GDP per capita growth & $\begin{array}{c}0.383 * * * \\
(0.036)\end{array}$ & $\begin{array}{c}0.383 * * * \\
(0.036)\end{array}$ & $\begin{array}{c}0.380 * * * \\
(0.036)\end{array}$ & $\begin{array}{c}0.381 * * * \\
(0.037)\end{array}$ & $\begin{array}{c}0.378 * * * \\
(0.037)\end{array}$ & $\begin{array}{c}0.380 * * * \\
(0.037)\end{array}$ & $\begin{array}{c}0.381 * * * \\
(0.037)\end{array}$ \\
\hline Population growth & $\begin{array}{c}-0.477 * * * \\
(0.064)\end{array}$ & $\begin{array}{c}-0.477 * * * \\
(0.064)\end{array}$ & $\begin{array}{c}-0.474 * * * \\
(0.064)\end{array}$ & $\begin{array}{c}-0.483 * * * \\
(0.064)\end{array}$ & $\begin{array}{c}-0.478 * * * \\
(0.064)\end{array}$ & $\begin{array}{c}-0.477 * * * \\
(0.064)\end{array}$ & $\begin{array}{c}-0.483 * * * \\
(0.065)\end{array}$ \\
\hline Investment growth & $\begin{array}{l}0.02 \\
(0.0\end{array}$ & $\begin{array}{l}0.023 * \\
(0.014)\end{array}$ & $\begin{array}{c}0.023^{*} \\
(0.014)\end{array}$ & $\begin{array}{c}0.023 * \\
(0.014)\end{array}$ & $\begin{array}{c}0.023 * \\
(0.014)\end{array}$ & $\begin{array}{c}0.023 * \\
(0.014)\end{array}$ & $\begin{array}{l}0.023 * \\
(0.014)\end{array}$ \\
\hline Openness & $\begin{array}{c}0.007 * * * \\
(0.002)\end{array}$ & $\begin{array}{c}0.007 * * * \\
(0.002)\end{array}$ & $\begin{array}{c}0.007 * * * \\
(0.002)\end{array}$ & $\begin{array}{c}0.008 * * * \\
(0.002)\end{array}$ & $\begin{array}{c}0.008 * * * \\
(0.002)\end{array}$ & $\begin{array}{c}0.008 * * * \\
(0.002)\end{array}$ & $\begin{array}{c}0.008 * * * \\
(0.002)\end{array}$ \\
\hline School enrollment & $\begin{array}{c}-0.004 \\
(0.006)\end{array}$ & $\begin{array}{c}-0.004 \\
(0.006)\end{array}$ & $\begin{array}{c}-0.004 \\
(0.006)\end{array}$ & $\begin{array}{c}-0.003 \\
(0.006)\end{array}$ & $\begin{array}{c}-0.002 \\
(0.006)\end{array}$ & $\begin{array}{c}-0.003 \\
(0.006)\end{array}$ & $\begin{array}{c}-0.003 \\
(0.006)\end{array}$ \\
\hline Inflation & $\begin{array}{c}-0.031 * * * \\
(0.011)\end{array}$ & $\begin{array}{c}-0.031 * * * \\
(0.011)\end{array}$ & $\begin{array}{c}-0.031 * * * \\
(0.011)\end{array}$ & $\begin{array}{c}-0.031 * * * \\
(0.011)\end{array}$ & $\begin{array}{c}-0.031 * * * \\
(0.011)\end{array}$ & $\begin{array}{c}-0.031 * * * \\
(0.011)\end{array}$ & $\begin{array}{c}-0.031 * * * \\
(0.011)\end{array}$ \\
\hline Initial GDP per capita & $\begin{array}{c}-0.000 * * * \\
(0.000)\end{array}$ & $\begin{array}{c}-0.000 * * * \\
(0.000)\end{array}$ & $\begin{array}{c}-0.000 * * * \\
(0.000)\end{array}$ & $\begin{array}{c}-0.000 * * * \\
(0.000)\end{array}$ & $\begin{array}{c}-0.000 * * * \\
(0.000)\end{array}$ & $\begin{array}{c}-0.000 * * * \\
(0.000)\end{array}$ & $\begin{array}{c}-0.000 * * * \\
(0.000)\end{array}$ \\
\hline Dev: High income & $\begin{array}{c}-0.314 \\
(0.400)\end{array}$ & $\begin{array}{c}-0.313 \\
(0.402)\end{array}$ & $\begin{array}{c}-0.301 \\
(0.402)\end{array}$ & $\begin{array}{c}-0.316 \\
(0.400)\end{array}$ & $\begin{array}{c}-0.292 \\
(0.401)\end{array}$ & $\begin{array}{c}-0.313 \\
(0.398)\end{array}$ & $\begin{array}{c}-0.311 \\
(0.401)\end{array}$ \\
\hline Dev: Upper middle-income & $\begin{array}{c}0.132 \\
(0.372)\end{array}$ & $\begin{array}{c}0.133 \\
(0.374)\end{array}$ & $\begin{array}{c}0.122 \\
(0.374)\end{array}$ & $\begin{array}{c}0.101 \\
(0.371)\end{array}$ & $\begin{array}{c}0.122 \\
(0.375)\end{array}$ & $\begin{array}{c}0.118 \\
(0.370)\end{array}$ & $\begin{array}{c}0.108 \\
(0.373)\end{array}$ \\
\hline Dev: Lower middle-income & $\begin{array}{c}0.217 \\
(0.316)\end{array}$ & $\begin{array}{c}0.217 \\
(0.317)\end{array}$ & $\begin{array}{c}0.218 \\
(0.317)\end{array}$ & $\begin{array}{c}0.198 \\
(0.317)\end{array}$ & $\begin{array}{c}0.218 \\
(0.321)\end{array}$ & $\begin{array}{c}0.219 \\
(0.316)\end{array}$ & $\begin{array}{c}0.196 \\
(0.317)\end{array}$ \\
\hline Constant & $\begin{array}{c}2.018 * * * \\
(0.689)\end{array}$ & $\begin{array}{c}2.015^{*} * * \\
(0.690)\end{array}$ & $\begin{array}{c}2.013 * * * \\
(0.687)\end{array}$ & $\begin{array}{c}1.933 * * * \\
(0.690)\end{array}$ & $\begin{array}{c}1.894 * * * \\
(0.693)\end{array}$ & $\begin{array}{c}1.972 * * * \\
(0.687)\end{array}$ & $\begin{array}{c}1.948 * * * \\
(0.698)\end{array}$ \\
\hline Observations & 2,686 & 2,686 & 2,686 & 2,681 & 2,681 & 2,684 & 2,681 \\
\hline
\end{tabular}

Robust standard errors in parentheses; *** $\mathrm{p}<0.01, * * \mathrm{p}<0.05, * \mathrm{p}<0.1 ; \mathrm{P}$-values for $\Delta$ CC is 0.131 .

Generalized least squares (GLS) estimations. 


\section{Rashid Nikzad}

Governance, Institutions, and Economic Development

Table A2.2: GDP per capita growth and governance, 1996-2019 - High-income countries

\begin{tabular}{|c|c|c|c|c|c|c|c|}
\hline GDP per capita growth & & $\Delta \mathrm{VA}$ & $\triangle \mathrm{PV}$ & $\Delta \mathrm{GE}$ & $\Delta \mathrm{RQ}$ & $\Delta \mathrm{RL}$ & $\Delta \mathrm{CC}$ \\
\hline Governance indicator & & $\begin{array}{c}-2.054 \\
(1.972)\end{array}$ & $\begin{array}{c}1.185^{* * *} \\
(0.380)\end{array}$ & $\begin{array}{l}1.052 * \\
(0.741)\end{array}$ & $\begin{array}{c}2.849 * * * \\
(0.801)\end{array}$ & $\begin{array}{l}2.562 * * \\
(1.054)\end{array}$ & $\begin{array}{l}2.957 * \\
(1.703)\end{array}$ \\
\hline Lag of GDP per capita growth & $\begin{array}{c}0.372 * * * \\
(0.040)\end{array}$ & $\begin{array}{c}0.369 * * * \\
(0.038)\end{array}$ & $\begin{array}{c}0.372 * * * \\
(0.041)\end{array}$ & $\begin{array}{c}0.370 * * * \\
(0.040)\end{array}$ & $\begin{array}{c}0.366 * * * \\
(0.040)\end{array}$ & $\begin{array}{c}0.366 * * * \\
(0.041)\end{array}$ & $\begin{array}{c}0.374 * * * \\
(0.043)\end{array}$ \\
\hline Population growth & $\begin{array}{c}-0.421 * * * \\
(0.064)\end{array}$ & $\begin{array}{c}-0.424 * * * \\
(0.062)\end{array}$ & $\begin{array}{c}-0.418 * * * \\
(0.063)\end{array}$ & $\begin{array}{c}-0.433 * * * \\
(0.061)\end{array}$ & $\begin{array}{c}-0.425 * * * \\
(0.065)\end{array}$ & $\begin{array}{c}-0.426 * * * \\
(0.064)\end{array}$ & $\begin{array}{c}-0.419 * * * \\
(0.071)\end{array}$ \\
\hline Investment growth & $\begin{array}{c}0.083 * * * \\
(0.018)\end{array}$ & $\begin{array}{c}0.083 * * * \\
(0.018)\end{array}$ & $\begin{array}{c}0.083 * * * \\
(0.018)\end{array}$ & $\begin{array}{c}0.083 * * * \\
(0.018)\end{array}$ & $\begin{array}{c}0.080 * * * \\
(0.018)\end{array}$ & $\begin{array}{c}0.084 * * * \\
(0.018)\end{array}$ & $\begin{array}{c}0.081 * * * \\
(0.019)\end{array}$ \\
\hline Openness & $\begin{array}{c}0.006 * * * \\
(0.001)\end{array}$ & $\begin{array}{c}0.006 * * * \\
(0.001)\end{array}$ & $\begin{array}{c}0.006 * * * \\
(0.001)\end{array}$ & $\begin{array}{c}0.006 * * * \\
(0.001)\end{array}$ & $\begin{array}{c}0.006 * * * \\
(0.001)\end{array}$ & $\begin{array}{c}0.006 * * * \\
(0.001)\end{array}$ & $\begin{array}{c}0.006 * * * \\
(0.001)\end{array}$ \\
\hline School enrollment & $\begin{array}{c}-0.008 \\
(0.017)\end{array}$ & $\begin{array}{c}-0.007 \\
(0.017)\end{array}$ & $\begin{array}{c}-0.008 \\
(0.017)\end{array}$ & $\begin{array}{c}-0.002 \\
(0.017)\end{array}$ & $\begin{array}{c}-0.002 \\
(0.017)\end{array}$ & $\begin{array}{c}-0.005 \\
(0.016)\end{array}$ & $\begin{array}{c}-0.001 \\
(0.016)\end{array}$ \\
\hline Inflation & $\begin{array}{c}-0.047 * * * \\
(0.009)\end{array}$ & $\begin{array}{c}-0.047 * * * \\
(0.009)\end{array}$ & $\begin{array}{c}-0.046 * * * \\
(0.009)\end{array}$ & $\begin{array}{c}-0.045 * * * \\
(0.009)\end{array}$ & $\begin{array}{c}-0.049 * * * \\
(0.010)\end{array}$ & $\begin{array}{c}-0.046 * * * \\
(0.009)\end{array}$ & $\begin{array}{c}-0.045^{* * *} * \\
(0.010)\end{array}$ \\
\hline Initial GDP per capita & $\begin{array}{c}-0.000 * * * \\
(0.000)\end{array}$ & $\begin{array}{c}-0.000 * * * \\
(0.000)\end{array}$ & $\begin{array}{c}-0.000 * * * \\
(0.000)\end{array}$ & $\begin{array}{c}-0.000 * * * \\
(0.000)\end{array}$ & $\begin{array}{c}-0.000 * * * \\
(0.000)\end{array}$ & $\begin{array}{c}-0.000 * * * \\
(0.000)\end{array}$ & $\begin{array}{c}-0.000 * * * \\
(0.000)\end{array}$ \\
\hline Constant & $\begin{array}{c}1.243 \\
(2.560)\end{array}$ & $\begin{array}{c}1.143 \\
(2.555)\end{array}$ & $\begin{array}{c}1.329 \\
(2.583)\end{array}$ & $\begin{array}{c}0.622 \\
(2.564)\end{array}$ & $\begin{array}{c}0.599 \\
(2.637)\end{array}$ & $\begin{array}{c}0.876 \\
(2.537)\end{array}$ & $\begin{array}{c}0.403 \\
(2.558)\end{array}$ \\
\hline Observations & 1,013 & 1,013 & 1,013 & 1,008 & 1,008 & 1,011 & 1,008 \\
\hline
\end{tabular}

Robust standard errors in parentheses; *** $\mathrm{p}<0.01, * * \mathrm{p}<0.05, * \mathrm{p}<0.1 ;$ P-values for $\Delta \mathrm{GE}$ is 0.156 .

Generalized least squares (GLS) estimations.

Table A2.3: GDP per capita growth and governance, 1996-2019 - High middle-income countries

\begin{tabular}{|c|c|c|c|c|c|c|c|}
\hline GDP per capita growth & & $\triangle \mathrm{VA}$ & $\triangle \mathrm{PV}$ & $\Delta \mathrm{GE}$ & $\Delta \mathrm{RQ}$ & $\Delta \mathrm{RL}$ & $\Delta \mathrm{CC}$ \\
\hline Governance indicator & & $\begin{array}{c}-1.137 \\
(0.894)\end{array}$ & $\begin{array}{c}0.313 \\
(0.555)\end{array}$ & $\begin{array}{c}0.244 \\
(0.884)\end{array}$ & $\begin{array}{c}1.519 \\
(1.145)\end{array}$ & $\begin{array}{c}-0.013 \\
(1.382)\end{array}$ & $\begin{array}{c}-0.047 \\
(1.023)\end{array}$ \\
\hline Lag of GDP per capita growth & $\begin{array}{c}0.374 * * * \\
(0.088)\end{array}$ & $\begin{array}{c}0.371 * * * \\
(0.088)\end{array}$ & $\begin{array}{c}0.373 * * * \\
(0.088)\end{array}$ & $\begin{array}{c}0.374 * * * \\
(0.088)\end{array}$ & $\begin{array}{c}0.373 * * * \\
(0.088)\end{array}$ & $\begin{array}{c}0.374 * * * \\
(0.088)\end{array}$ & $\begin{array}{c}0.374 * * * \\
(0.089)\end{array}$ \\
\hline Population growth & $\begin{array}{c}-0.772 * * * \\
(0.162)\end{array}$ & $\begin{array}{c}-0.778 * * * \\
(0.163)\end{array}$ & $\begin{array}{c}-0.770 * * * \\
(0.164)\end{array}$ & $\begin{array}{c}-0.770 * * * \\
(0.165)\end{array}$ & $\begin{array}{c}-0.758^{* * *} * \\
(0.166)\end{array}$ & $\begin{array}{c}-0.772 * * * \\
(0.163)\end{array}$ & $\begin{array}{c}-0.772 * * * \\
(0.163)\end{array}$ \\
\hline Investment growth & $\begin{array}{c}0.042^{* *} \\
(0.019)\end{array}$ & $\begin{array}{c}0.043^{* *} * \\
(0.019)\end{array}$ & $\begin{array}{c}0.042 * * \\
(0.019)\end{array}$ & $\begin{array}{c}0.042 * * \\
(0.019)\end{array}$ & $\begin{array}{c}0.041 * * \\
(0.018)\end{array}$ & $\begin{array}{c}0.042 * * \\
(0.019)\end{array}$ & $\begin{array}{c}0.042 * * \\
(0.019)\end{array}$ \\
\hline Openness & $\begin{array}{c}0.006 \\
(0.006)\end{array}$ & $\begin{array}{c}0.006 \\
(0.006)\end{array}$ & $\begin{array}{c}0.006 \\
(0.006)\end{array}$ & $\begin{array}{c}0.006 \\
(0.006)\end{array}$ & $\begin{array}{c}0.006 \\
(0.006)\end{array}$ & $\begin{array}{c}0.006 \\
(0.006)\end{array}$ & $\begin{array}{c}0.006 \\
(0.006)\end{array}$ \\
\hline School enrollment & $\begin{array}{l}-0.001 \\
(0.017)\end{array}$ & $\begin{array}{l}-0.000 \\
(0.017)\end{array}$ & $\begin{array}{c}-0.001 \\
(0.017)\end{array}$ & $\begin{array}{l}-0.000 \\
(0.017)\end{array}$ & $\begin{array}{c}-0.000 \\
(0.016)\end{array}$ & $\begin{array}{c}-0.001 \\
(0.017)\end{array}$ & $\begin{array}{c}-0.001 \\
(0.017)\end{array}$ \\
\hline Inflation & $\begin{array}{c}-0.047 * * * \\
(0.017)\end{array}$ & $\begin{array}{c}-0.048 * * * \\
(0.017)\end{array}$ & $\begin{array}{c}-0.047 * * * \\
(0.017)\end{array}$ & $\begin{array}{c}-0.047 * * * \\
(0.017)\end{array}$ & $\begin{array}{c}-0.047 * * * \\
(0.016)\end{array}$ & $\begin{array}{c}-0.047 * * * \\
(0.017)\end{array}$ & $\begin{array}{c}-0.047 * * * \\
(0.017)\end{array}$ \\
\hline Initial GDP per capita & $\begin{array}{c}-0.000 * * * \\
(0.000)\end{array}$ & $\begin{array}{c}-0.000 * * * \\
(0.000)\end{array}$ & $\begin{array}{c}-0.000 * * * \\
(0.000)\end{array}$ & $\begin{array}{c}-0.000 * * * \\
(0.000)\end{array}$ & $\begin{array}{c}-0.000 * * * \\
(0.000)\end{array}$ & $\begin{array}{c}-0.000 * * * \\
(0.000)\end{array}$ & $\begin{array}{c}-0.000 * * * \\
(0.000)\end{array}$ \\
\hline Constant & $\begin{array}{l}3.429 * \\
(1.826)\end{array}$ & $\begin{array}{l}3.511^{*} \\
(1.830)\end{array}$ & $\begin{array}{l}3.425^{*} \\
(1.828)\end{array}$ & $\begin{array}{l}3.400 * \\
(1.841)\end{array}$ & $\begin{array}{l}3.360 * \\
(1.816)\end{array}$ & $\begin{array}{l}3.429 * \\
(1.827)\end{array}$ & $\begin{array}{l}3.434^{*} \\
(1.842)\end{array}$ \\
\hline Observations & 618 & 618 & 618 & 618 & 618 & 618 & 618 \\
\hline
\end{tabular}

Robust standard errors in parentheses; $* * * p<0.01, * * p<0.05, * p<0.1 ;$ P-values for $\Delta G E$ is 0.156.

Generalized least squares (GLS) estimations. 


\section{Rashid Nikzad}

Governance, Institutions, and Economic Development

Table A2.4: GDP per capita growth and governance, 1996-2019 - Low middle-income countries

\begin{tabular}{|c|c|c|c|c|c|c|c|}
\hline GDP per capita growth & & $\Delta \mathrm{VA}$ & $\Delta \mathrm{PV}$ & $\Delta \mathrm{GE}$ & $\Delta \mathrm{RQ}$ & $\Delta R L$ & $\Delta \mathrm{CC}$ \\
\hline Governance indicator & & $\begin{array}{c}-0.914 \\
(1.000)\end{array}$ & $\begin{array}{l}1.529 * * \\
(0.653)\end{array}$ & $\begin{array}{c}1.937 * \\
(0.996)\end{array}$ & $\begin{array}{c}1.394 \\
(1.038)\end{array}$ & $\begin{array}{c}2.080 * * \\
(0.973)\end{array}$ & $\begin{array}{c}0.383 \\
(0.970)\end{array}$ \\
\hline Lag of GDP per capita growth & $\begin{array}{c}0.346 * * * \\
(0.054)\end{array}$ & $\begin{array}{c}0.348 * * * \\
(0.054)\end{array}$ & $\begin{array}{c}0.333 * * * \\
(0.055)\end{array}$ & $\begin{array}{c}0.342 * * * \\
(0.052)\end{array}$ & $\begin{array}{c}0.343 * * * \\
(0.053)\end{array}$ & $\begin{array}{c}0.337 * * * \\
(0.055)\end{array}$ & $\begin{array}{c}0.345^{* * *} * \\
(0.053)\end{array}$ \\
\hline Population growth & $\begin{array}{c}-0.607 * * * \\
(0.128)\end{array}$ & $\begin{array}{c}-0.608 * * * \\
(0.128)\end{array}$ & $\begin{array}{c}-0.626 * * * \\
(0.127)\end{array}$ & $\begin{array}{c}-0.610 * * * \\
(0.126)\end{array}$ & $\begin{array}{c}-0.602 * * * \\
(0.128)\end{array}$ & $\begin{array}{c}-0.617 * * * \\
(0.128)\end{array}$ & $\begin{array}{c}-0.606 * * * \\
(0.129)\end{array}$ \\
\hline Investment growth & $\begin{array}{c}0.007 \\
(0.007)\end{array}$ & $\begin{array}{c}0.007 \\
(0.007)\end{array}$ & $\begin{array}{c}0.007 \\
(0.007)\end{array}$ & $\begin{array}{c}0.007 \\
(0.007)\end{array}$ & $\begin{array}{c}0.007 \\
(0.007)\end{array}$ & $\begin{array}{c}0.007 \\
(0.007)\end{array}$ & $\begin{array}{c}0.007 \\
(0.007)\end{array}$ \\
\hline Openness & $\begin{array}{c}0.005 \\
(0.004)\end{array}$ & $\begin{array}{c}0.005 \\
(0.004)\end{array}$ & $\begin{array}{c}0.005 \\
(0.004)\end{array}$ & $\begin{array}{c}0.005 \\
(0.004)\end{array}$ & $\begin{array}{c}0.005 \\
(0.004)\end{array}$ & $\begin{array}{c}0.005 \\
(0.004)\end{array}$ & $\begin{array}{c}0.005 \\
(0.004)\end{array}$ \\
\hline School enrollment & $\begin{array}{c}0.003 \\
(0.011)\end{array}$ & $\begin{array}{c}0.002 \\
(0.011)\end{array}$ & $\begin{array}{c}0.003 \\
(0.011)\end{array}$ & $\begin{array}{c}0.003 \\
(0.011)\end{array}$ & $\begin{array}{c}0.003 \\
(0.011)\end{array}$ & $\begin{array}{c}0.003 \\
(0.011)\end{array}$ & $\begin{array}{c}0.003 \\
(0.011)\end{array}$ \\
\hline Inflation & $\begin{array}{c}0.019 * * * \\
(0.007)\end{array}$ & $\begin{array}{c}0.019 * * * \\
(0.007)\end{array}$ & $\begin{array}{c}0.017 * * \\
(0.008)\end{array}$ & $\begin{array}{c}0.018 * * \\
(0.008)\end{array}$ & $\begin{array}{c}0.017 * * \\
(0.008)\end{array}$ & $\begin{array}{c}0.020 * * * \\
(0.008)\end{array}$ & $\begin{array}{c}0.019 * * \\
(0.007)\end{array}$ \\
\hline Initial GDP per capita & $\begin{array}{c}-0.000 * * * \\
(0.000)\end{array}$ & $\begin{array}{c}-0.000 * * * \\
(0.000)\end{array}$ & $\begin{array}{c}-0.000 * * * \\
(0.000)\end{array}$ & $\begin{array}{c}-0.000 * * * \\
(0.000)\end{array}$ & $\begin{array}{c}-0.000 * * * \\
(0.000)\end{array}$ & $\begin{array}{c}-0.000 * * * \\
(0.000)\end{array}$ & $\begin{array}{c}-0.000 * * * \\
(0.000)\end{array}$ \\
\hline Constant & $\begin{array}{c}2.895 * * \\
(1.259)\end{array}$ & $\begin{array}{c}2.926 * * \\
(1.267)\end{array}$ & $\begin{array}{c}2.955^{* *} \\
(1.246)\end{array}$ & $\begin{array}{c}2.870 * * \\
(1.245)\end{array}$ & $\begin{array}{c}2.831 * * \\
(1.266)\end{array}$ & $\begin{array}{c}2.917 * * \\
(1.259)\end{array}$ & $\begin{array}{c}2.897 * * \\
(1.254)\end{array}$ \\
\hline Observations & 738 & 738 & 738 & 738 & 738 & 738 & 738 \\
\hline
\end{tabular}

Robust standard errors in parentheses; $* * * p<0.01, * * p<0.05, * p<0.1$; Generalized least squares (GLS) estimations.

Table A2.5: GDP per capita growth and governance, 1996-2019 - Low-income countries

\begin{tabular}{|c|c|c|c|c|c|c|c|}
\hline GDP per capita growth & & $\Delta \mathrm{VA}$ & $\triangle \mathrm{PV}$ & $\Delta \mathrm{GE}$ & $\Delta \mathrm{RQ}$ & $\Delta \mathrm{RL}$ & $\triangle \mathrm{CC}$ \\
\hline Governance indicator & & $\begin{array}{l}\text { 3.506* } \\
(2.191)\end{array}$ & $\begin{array}{c}2.047 * * * \\
(0.718)\end{array}$ & $\begin{array}{c}-0.805 \\
(3.312)\end{array}$ & $\begin{array}{c}-1.532 \\
(2.533)\end{array}$ & $\begin{array}{c}5.797 \\
(4.310)\end{array}$ & $\begin{array}{c}-2.536 \\
(2.059)\end{array}$ \\
\hline Lag of GDP per capita growth & $\begin{array}{c}0.236 * * * \\
(0.066)\end{array}$ & $\begin{array}{c}0.243 * * * \\
(0.065)\end{array}$ & $\begin{array}{c}0.240 * * * \\
(0.067)\end{array}$ & $\begin{array}{c}0.237 * * * \\
(0.067)\end{array}$ & $\begin{array}{c}0.237 * * * \\
(0.065)\end{array}$ & $\begin{array}{c}0.244 * * * \\
(0.065)\end{array}$ & $\begin{array}{c}0.240 * * * \\
(0.064)\end{array}$ \\
\hline Population growth & $\begin{array}{c}0.549 \\
(0.657)\end{array}$ & $\begin{array}{c}0.540 \\
(0.663)\end{array}$ & $\begin{array}{c}0.570 \\
(0.670)\end{array}$ & $\begin{array}{c}0.544 \\
(0.666)\end{array}$ & $\begin{array}{c}0.543 \\
(0.663)\end{array}$ & $\begin{array}{c}0.529 \\
(0.605)\end{array}$ & $\begin{array}{c}0.561 \\
(0.655)\end{array}$ \\
\hline Investment growth & $\begin{array}{c}0.039 * * * \\
(0.014)\end{array}$ & $\begin{array}{c}0.037 * * * \\
(0.013)\end{array}$ & $\begin{array}{c}0.038 * * * \\
(0.014)\end{array}$ & $\begin{array}{c}0.040 * * * \\
(0.014)\end{array}$ & $\begin{array}{c}0.040 * * * \\
(0.014)\end{array}$ & $\begin{array}{c}0.039 * * * \\
(0.013)\end{array}$ & $\begin{array}{c}0.040 * * * \\
(0.013)\end{array}$ \\
\hline Openness & $\begin{array}{c}0.017 * \\
(0.009)\end{array}$ & $\begin{array}{c}0.014 \\
(0.010)\end{array}$ & $\begin{array}{c}0.015^{*} \\
(0.009)\end{array}$ & $\begin{array}{l}0.017^{*} \\
(0.009)\end{array}$ & $\begin{array}{l}0.017^{*} \\
(0.009)\end{array}$ & $\begin{array}{c}0.015 \\
(0.009)\end{array}$ & $\begin{array}{c}0.018 * * \\
(0.009)\end{array}$ \\
\hline School enrollment & $\begin{array}{c}-0.010 \\
(0.012)\end{array}$ & $\begin{array}{c}-0.008 \\
(0.012)\end{array}$ & $\begin{array}{c}-0.010 \\
(0.011)\end{array}$ & $\begin{array}{c}-0.010 \\
(0.012)\end{array}$ & $\begin{array}{l}-0.010 \\
(0.012)\end{array}$ & $\begin{array}{c}-0.009 \\
(0.011)\end{array}$ & $\begin{array}{l}-0.010 \\
(0.011)\end{array}$ \\
\hline Inflation & $\begin{array}{c}0.021 \\
(0.041)\end{array}$ & $\begin{array}{c}0.017 \\
(0.041)\end{array}$ & $\begin{array}{c}0.015 \\
(0.040)\end{array}$ & $\begin{array}{c}0.021 \\
(0.041)\end{array}$ & $\begin{array}{c}0.022 \\
(0.040)\end{array}$ & $\begin{array}{c}0.014 \\
(0.039)\end{array}$ & $\begin{array}{c}0.021 \\
(0.040)\end{array}$ \\
\hline Initial GDP per capita & $\begin{array}{l}-0.001 \\
(0.001)\end{array}$ & $\begin{array}{c}-0.001 \\
(0.001)\end{array}$ & $\begin{array}{c}-0.001 \\
(0.001)\end{array}$ & $\begin{array}{c}-0.001 \\
(0.001)\end{array}$ & $\begin{array}{l}-0.001 \\
(0.001)\end{array}$ & $\begin{array}{c}-0.001 \\
(0.001)\end{array}$ & $\begin{array}{l}-0.001 \\
(0.001)\end{array}$ \\
\hline Constant & $\begin{array}{c}0.009 \\
(3.021)\end{array}$ & $\begin{array}{c}0.085 \\
(2.980)\end{array}$ & $\begin{array}{l}-0.055 \\
(3.023)\end{array}$ & $\begin{array}{c}0.040 \\
(3.092)\end{array}$ & $\begin{array}{c}0.032 \\
(3.038)\end{array}$ & $\begin{array}{c}0.081 \\
(2.807)\end{array}$ & $\begin{array}{l}-0.091 \\
(3.022)\end{array}$ \\
\hline Observations & 317 & 317 & 317 & 317 & 317 & 317 & 317 \\
\hline
\end{tabular}

Robust standard errors in parentheses; $* * * \mathrm{p}<0.01, * * \mathrm{p}<0.05, * \mathrm{p}<0.1 ; \mathrm{P}$-values for $\Delta \mathrm{VA}$ is 0.110 ; Generalized least squares (GLS) estimations. 
Rashid Nikzad

Governance, Institutions, and Economic Development

Appendix 3: GDP growth and governance, 1996-2019 - All countries

\begin{tabular}{|c|c|c|c|c|c|c|}
\hline GDP per capita growth & $\begin{array}{c}\text { All } \\
\text { countries }\end{array}$ & $\begin{array}{c}\text { All } \\
\text { countries }\end{array}$ & $\begin{array}{c}\text { High- } \\
\text { income } \\
\text { countries }\end{array}$ & $\begin{array}{c}\text { High } \\
\text { middle- } \\
\text { income } \\
\text { countries }\end{array}$ & $\begin{array}{c}\text { Low } \\
\text { middle- } \\
\text { income } \\
\text { countries }\end{array}$ & $\begin{array}{c}\text { Low- } \\
\text { income } \\
\text { countries }\end{array}$ \\
\hline$\Delta \mathrm{VA}$ & & $\begin{array}{c}-0.690 \\
(0.913)\end{array}$ & $\begin{array}{l}-2.913 * \\
(1.532)\end{array}$ & $\begin{array}{c}-0.494 \\
(0.934)\end{array}$ & $\begin{array}{c}-1.413^{*} \\
(0.954)\end{array}$ & $\begin{array}{c}2.442 \\
(1.826)\end{array}$ \\
\hline$\triangle \mathrm{PV}$ & & $\begin{array}{c}1.173 * * * \\
(0.330)\end{array}$ & $\begin{array}{c}0.827 * \\
(0.529)\end{array}$ & $\begin{array}{c}0.232 \\
(0.571)\end{array}$ & $\begin{array}{l}1.568 * \\
(0.821)\end{array}$ & $\begin{array}{c}0.896 \\
(0.724)\end{array}$ \\
\hline$\Delta \mathrm{GE}$ & & $\begin{array}{c}-0.192 \\
(0.635)\end{array}$ & $\begin{array}{c}0.017 \\
(0.864)\end{array}$ & $\begin{array}{c}-0.015 \\
(0.979)\end{array}$ & $\begin{array}{c}0.746 \\
(1.016)\end{array}$ & $\begin{array}{c}-1.663 \\
(2.860)\end{array}$ \\
\hline$\Delta \mathrm{RQ}$ & & $\begin{array}{c}1.786 * * * \\
(0.552)\end{array}$ & $\begin{array}{c}1.837 * * * \\
(0.579)\end{array}$ & $\begin{array}{l}2.023 * \\
(1.041)\end{array}$ & $\begin{array}{c}1.014 \\
(0.992)\end{array}$ & $\begin{array}{c}0.003 \\
(2.427)\end{array}$ \\
\hline$\Delta \mathrm{RL}$ & & $\begin{array}{c}1.361 * \\
(0.897)\end{array}$ & $\begin{array}{l}1.382 * \\
(0.881)\end{array}$ & $\begin{array}{c}-0.365 \\
(1.563)\end{array}$ & $\begin{array}{c}1.391 * \\
(0.936)\end{array}$ & $\begin{array}{c}4.553 \\
(3.888)\end{array}$ \\
\hline$\Delta \mathrm{CC}$ & & $\begin{array}{c}0.596 \\
(1.047)\end{array}$ & $\begin{array}{c}2.056 \\
(1.658)\end{array}$ & $\begin{array}{c}0.101 \\
(1.116)\end{array}$ & $\begin{array}{c}-0.157 \\
(0.902)\end{array}$ & $\begin{array}{c}-3.098 \\
(2.199)\end{array}$ \\
\hline Lag of GDP per capita growth & $\begin{array}{c}0.395 * * * \\
(0.037)\end{array}$ & $\begin{array}{c}0.386 * * * \\
(0.037)\end{array}$ & $\begin{array}{c}0.396 * * * \\
(0.035)\end{array}$ & $\begin{array}{c}0.407 * * * \\
(0.099)\end{array}$ & $\begin{array}{c}0.349 * * * \\
(0.056)\end{array}$ & $\begin{array}{c}0.257 * * * \\
(0.073)\end{array}$ \\
\hline Population growth & $\begin{array}{c}0.074 \\
(0.066)\end{array}$ & $\begin{array}{c}0.083 \\
(0.065)\end{array}$ & $\begin{array}{c}0.094 * \\
(0.052)\end{array}$ & $\begin{array}{c}-0.159 \\
(0.153)\end{array}$ & $\begin{array}{c}0.260 * * \\
(0.126)\end{array}$ & $\begin{array}{c}1.432 * * * \\
(0.508)\end{array}$ \\
\hline Investment growth & $\begin{array}{l}0.024 * \\
(0.014)\end{array}$ & $\begin{array}{c}0.023 * \\
(0.014)\end{array}$ & $\begin{array}{c}0.081 * * * \\
(0.018)\end{array}$ & $\begin{array}{c}0.043 * * \\
(0.020)\end{array}$ & $\begin{array}{c}0.007 \\
(0.007)\end{array}$ & $\begin{array}{c}0.043 * * * \\
(0.014)\end{array}$ \\
\hline Openness & $\begin{array}{c}0.007 * * * \\
(0.002)\end{array}$ & $\begin{array}{c}0.007 * * * \\
(0.002)\end{array}$ & $\begin{array}{c}0.005 * * \\
(0.002)\end{array}$ & $\begin{array}{c}0.005 \\
(0.005)\end{array}$ & $\begin{array}{l}0.007 * \\
(0.004)\end{array}$ & $\begin{array}{c}0.023 * * \\
(0.012)\end{array}$ \\
\hline School enrollment & $\begin{array}{c}-0.004 \\
(0.006)\end{array}$ & $\begin{array}{c}-0.003 \\
(0.006)\end{array}$ & $\begin{array}{c}-0.001 \\
(0.017)\end{array}$ & $\begin{array}{c}-0.017 \\
(0.014)\end{array}$ & $\begin{array}{c}0.006 \\
(0.011)\end{array}$ & $\begin{array}{c}0.001 \\
(0.009)\end{array}$ \\
\hline Inflation & $\begin{array}{c}-0.031 * * * \\
(0.012)\end{array}$ & $\begin{array}{c}-0.031 * * * \\
(0.011)\end{array}$ & $\begin{array}{c}-0.038^{* * *} * \\
(0.010)\end{array}$ & $\begin{array}{c}-0.048 * * * \\
(0.018)\end{array}$ & $\begin{array}{c}0.012 \\
(0.009)\end{array}$ & $\begin{array}{c}-0.061 * \\
(0.034)\end{array}$ \\
\hline Initial GDP per capita & $\begin{array}{c}0.000 \\
(0.000)\end{array}$ & $\begin{array}{c}0.000 \\
(0.000)\end{array}$ & $\begin{array}{c}-0.000 \\
(0.000)\end{array}$ & $\begin{array}{c}0.000 \\
(0.000)\end{array}$ & $\begin{array}{c}0.000 * * * \\
(0.000)\end{array}$ & $\begin{array}{c}0.000 * * * \\
(0.000)\end{array}$ \\
\hline Dev: High income & $\begin{array}{c}-1.220 * * * \\
(0.300)\end{array}$ & $\begin{array}{c}-1.208 * * * \\
(0.307)\end{array}$ & & & & \\
\hline Dev: Upper middle-income & $\begin{array}{c}-0.175 \\
(0.337)\end{array}$ & $\begin{array}{c}-0.215 \\
(0.343)\end{array}$ & & & & \\
\hline Dev: Lower middle-income & $\begin{array}{c}0.106 \\
(0.303)\end{array}$ & $\begin{array}{c}0.101 \\
(0.308)\end{array}$ & & & & \\
\hline Constant & $\begin{array}{c}2.145^{* * *} \\
(0.665) \\
\end{array}$ & $\begin{array}{c}2.033 * * * \\
(0.667) \\
\end{array}$ & $\begin{array}{c}-0.374 \\
(2.710) \\
\end{array}$ & $\begin{array}{l}3.523 * \\
(1.892) \\
\end{array}$ & $\begin{array}{c}0.919 \\
(1.347)\end{array}$ & $\begin{array}{c}-3.076 \\
(2.134)\end{array}$ \\
\hline Observations & 2,686 & 2,681 & 1,008 & 618 & 738 & 317 \\
\hline
\end{tabular}

